\title{
Abusive head trauma: report of 3 cases
}

\author{
İstismara bağlı kafa travması: 3 olgu sunumu
}

\author{
Nilgün DEMİRLİ ÇAYLAN, ${ }^{1}$ Gonca YILMAZ, ${ }^{2}$ Resmiye ORAL, ${ }^{3}$ \\ Can Demir KARACAN, ${ }^{1}$ Pelin ZORLU ${ }^{1}$
}

\begin{abstract}
Abusive head trauma (AHT) is perpetrated when an infant or young child is shaken violently by an abuser, resulting in injuries to various intracranial structures, historically called "shaken baby syndrome" (SBS). Three cases of AHT with different constellations of clinical symptoms are presented here. Case 1- Three-month-old female infant was admitted with recurrent seizures, drowsiness, and low grade fever. Ophthalmologic examination revealed retinal hemorrhages $(\mathrm{RH})$ in the left eye. Computed tomography of cranium showed left frontal intra-parenchymal subdural hematoma (SDH). Case 2- Twelve-monthold male infant was admitted with a history of favoring left leg. Ophthalmologic examination revealed RH in the right eye. Cranial magnetic resonance imaging (MRI) revealed subacute SDH in the right frontoparietal region. Case 3- Three-month-old male infant was admitted with irritability and seizures. Ophthalmologic examination revealed bilateral disseminated RH. Cranial MRI scan showed bilateral frontoparietal subacute SDH. All cases were reported to Child Protective Services, who decided not to remove children from homes, but evaluated psychosocial risks and developed a safety plan, including home visits and family education. Physicians must be aware of possibility of AHT in infants presenting both subtle and overt neurologic symptoms. It is important to provide training on AHT to staff involved in the management of these cases.
\end{abstract}

Key Words: Abusive head trauma; childhood; retinal hemorrhage; shaken baby syndrome; subdural hematoma.
İstismara bağlı kafa travmasının bir formu, süt çocuğu veya küçük bir çocuğun istismarcı tarafindan şiddetle sarsılması ile ortaya çıkan, çeşitli intrakraniyal yapıların zedelenmesi ile sonuçlanan, tarihi adıyla "sarsılmış bebek sendromu"dur (SBS). Burada farklı klinik özellikleri olan 3 istismara bağlı kafa travması olgusu sunuldu. Olgu 1- Üç aylık kız bebek tekrarlayan nöbetler, uyuklama ve düşük derecede ateş yakınmaları ile kabul edildi. Oftalmolojik incelemede sol gözde retinal hemoraji (RH) saptandı. Kraniyal bilgisayarlı tomografi ile sol frontal bölgede intraparankimal subakut subdural hematom (SDH) gösterildi. Olgu 2- On iki aylık erkek bebek sol bacağının üzerine basamama yakınması ile kabul edildi. Oftalmolojik incelemede sağ gözde RH saptandı. Kraniyal manyetik rezonans görüntüleme (MRG) ile sağ frontoparyetal bölgede subakut SDH gösterildi. Olgu 3- Üç aylık erkek bebek irritabilte ve nöbet geçirme yakınmaları ile kabul edildi. Oftalmolojik incelemede iki taraflı yaygın RH saptandı. Kraniyal MRG ile iki taraflı frontoparyetal bölgede subakut SDH gösterildi. Olguların tümü, Çocuk Koruma Servisi'ne bildirildi ki bu servis psikososyal riskleri değerlendirerek ev ziyaretleri ve aile eğitimini içeren güvenli bir plan yaparak çocukları ailelerinden ayırmamaya karar verdi. Hekimler sinsi veya aşikar nörolojik semptomlarla başvuran süt çocuklarında istismara bağlı kafa travması olasığının farkında olmalıdırlar. Bu olguların yönetiminde rol alan tüm personele istismara bağlı kafa travması konusunda eğitim verilmesi önemlidir.

Anahtar Sözcükler: İstismara bağlı kafa travması; çocukluk çağı; retinal hemoraji; sarsılmış bebek sendromu; subdural hematom.
Departments of ${ }^{1}$ Pediatrics, ${ }^{2}$ Social Pediatrics, Dr. Sami Ulus Maternity and Children's Health and Diseases Training and Research Hospital, Ankara, Turkey;

${ }^{3}$ Department of Pediatrics, University of Iowa, Carver College of Medicine, Iowa City, Iowa, USA.
Dr. Sami Ulus Kadın Doğum Çocuk Sağlığı ve Hastalıkları Eğitim Araştırma Hastanesi, ${ }^{1}$ Genel Pediatri Kliniği, ${ }^{2}$ Sosyal Pediatri Kliniği, Ankara;

${ }^{3}$ Iowa Üniversitesi, Carver Tıp Fakültesi, Genel Pediatri Kliniği, Iowa Kenti, Iowa, ABD. 
Abusive head trauma (AHT) is perpetrated when an abuser violently shakes an infant, creating a whiplash motion and rotational acceleration/deceleration forces resulting in injuries to various intracranial structures, historically called "shaken baby syndrome" (SBS). Shaking may or may not be associated with impact; when it is, the trauma is called shaken impact syndrome, another form of AHT. The American Academy of Pediatrics published a position paper stating that although the terminology "shaken baby syndrome" should be used in prevention-focused projects and research efforts, diagnostic terminology should be replaced with "abusive head trauma," since shaking is not the only mechanism for inflicted traumatic brain injury. ${ }^{[1,2]}$ Incidence of AHT is based on limited studies and hospital records. It is believed to be much higher than reported because milder forms of AHT may not require a hospital visit. ${ }^{[3]}$ Extrapolation of the data from the few epidemiological studies revealed that SBS incidence may be as high as $15-30$ per 100.000 children under the age of one year. ${ }^{[4,5]}$ The estimation of fatality from this type of injury is $15-17 \%$ in affected children and morbidity in the form of serious neurological consequences may affect more than half of the survivors. ${ }^{[6]}$ Professional awareness of AHT is still poor in Turkey ${ }^{[7]}$ leading to rare diagnosis at hospital settings. Few cases have been reported previously. ${ }^{[8]}$ In this study, three cases of AHT with different constellations of clinical symptoms are presented to emphasize vital points.

\section{CASE REPORTS}

Case 1- A three-month-old female infant was admitted with recurrent seizures, drowsiness, and fever. After her parents noted irritability, she was diagnosed to have abdominal colic by her primary physician. Six hours later, she developed seizures localized to her right arm and was referred to the hospital. On arrival, she was lethargic, had a bulging anterior fontanel, and Glasgow coma score (GCS) was 12. Ophthalmologic examination revealed 5-6 small retinal hemorrhages $(\mathrm{RH})$ in zone 1 of posterior pole in the left eye. The rest of the physical examination was within normal limits. Complete blood count (CBC) including platelets, coagulation profile, renal and liver function tests were all within normal limits. The initial computed tomography $(\mathrm{CT})$ of cranium showed left frontal intraparenchymal acute subdural hematoma (SDH) (Figure 1) and brain edema around the intra-parenchymal bleeding. Cranial magnetic resonance imaging (MRI) scan verified the CT findings. Lumbar puncture (LP) revealed normal cerebrospinal findings. The parents were interviewed and the possibility of vigorous shaking was also explored. Although the mother reported that her three-year-old daughter hit the infant's head with a toy from time to time, she admitted to shaking the infant, which was triggered by inconsolable crying. She denied any inflicted impact. The neurosurgeon opted for conservative treatment approach with anti-edema and anti-seizure medication. The seizures were controlled by day 2 of admission, followed by

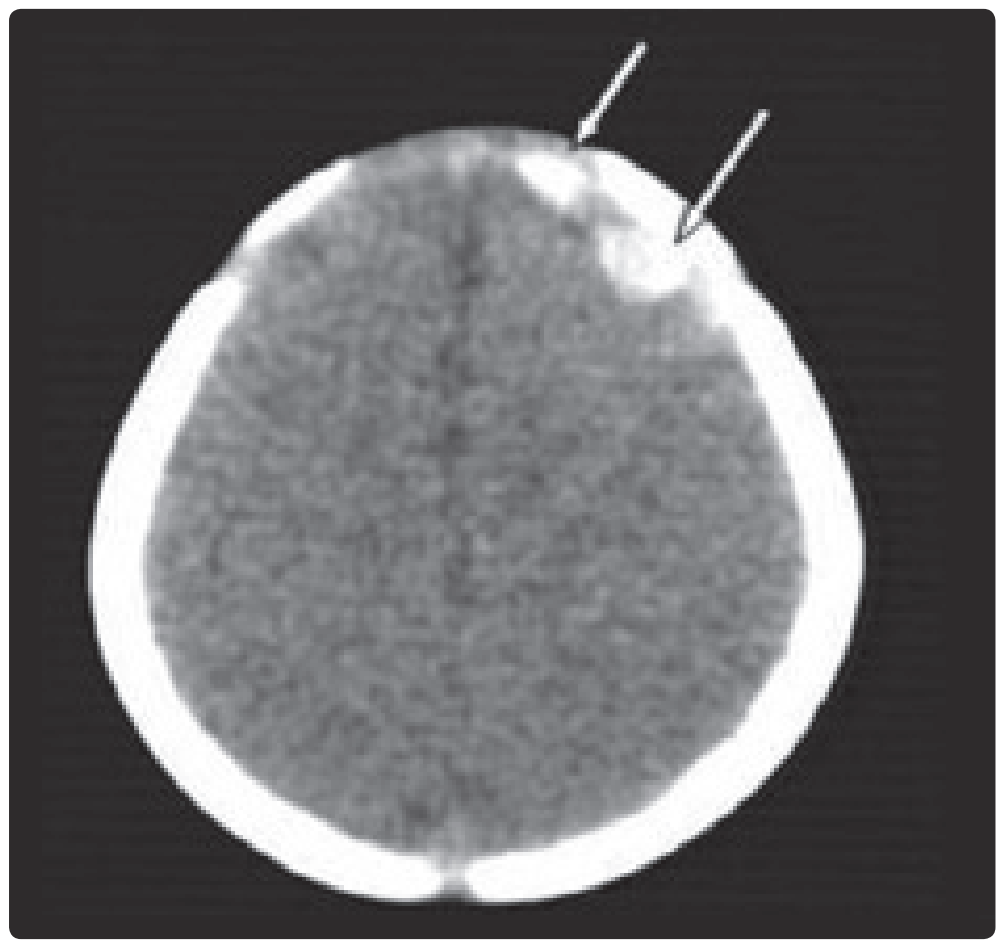

Fig. 1. Left frontal intracerebral and acute subdural hemorrhage in cranial computed tomography (Case 1). 

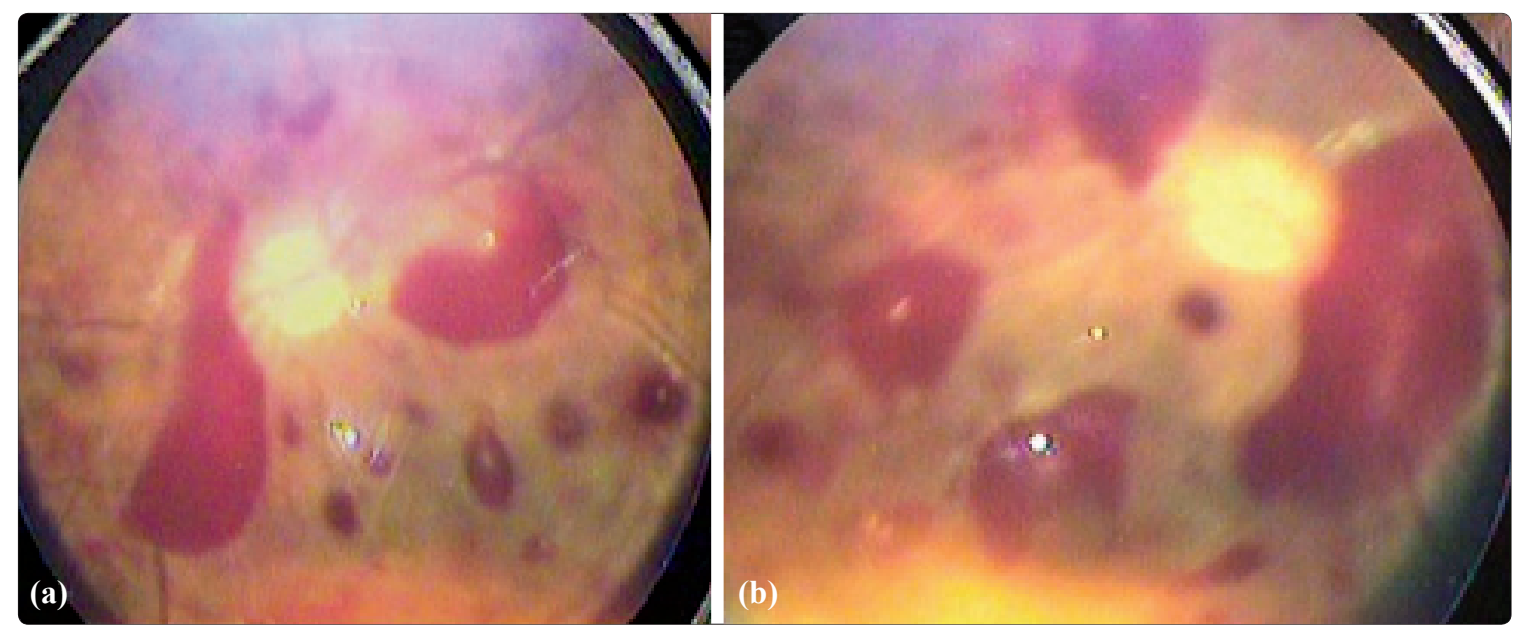

Fig. 2. (a, b) Bilateral disseminated intraretinal and preretinal hemorrhages (Right and left eye of Case 3).

(Color figures can be viewed in the online issue, which is available at www.tjtes.org).

mental status improvement and the patient's neurologic examination returning to normal. The infant was discharged on day 21 of admission.

Case 2- A twelve-month-old male infant was admitted with complaint of favoring his left leg. He was born at term gestation with unremarkable neonatal and post-neonatal course. On physical examination, his height, weight, and head circumference percentiles were compatible with his age. His neurologic examination revealed normal findings except for developmental delay. He could not sit without support. An ophthalmologic examination revealed 7-8 small $\mathrm{RH}$ in the right eye in zone 1 of posterior pole. Denver developmental test revealed a delay in crude motor activities. He was able to utter only two words (mom, dad). His CBC including platelets, coagulation profile, renal and liver function tests, and metabolic screening were all within normal limits. Cranial MRI revealed subacute $\mathrm{SDH}$ in the right frontoparietal region approximately 3-4 weeks old. His mother admitted to shaking the infant frequently on a recurrent basis. The last shaking was three weeks before the infant's hos-

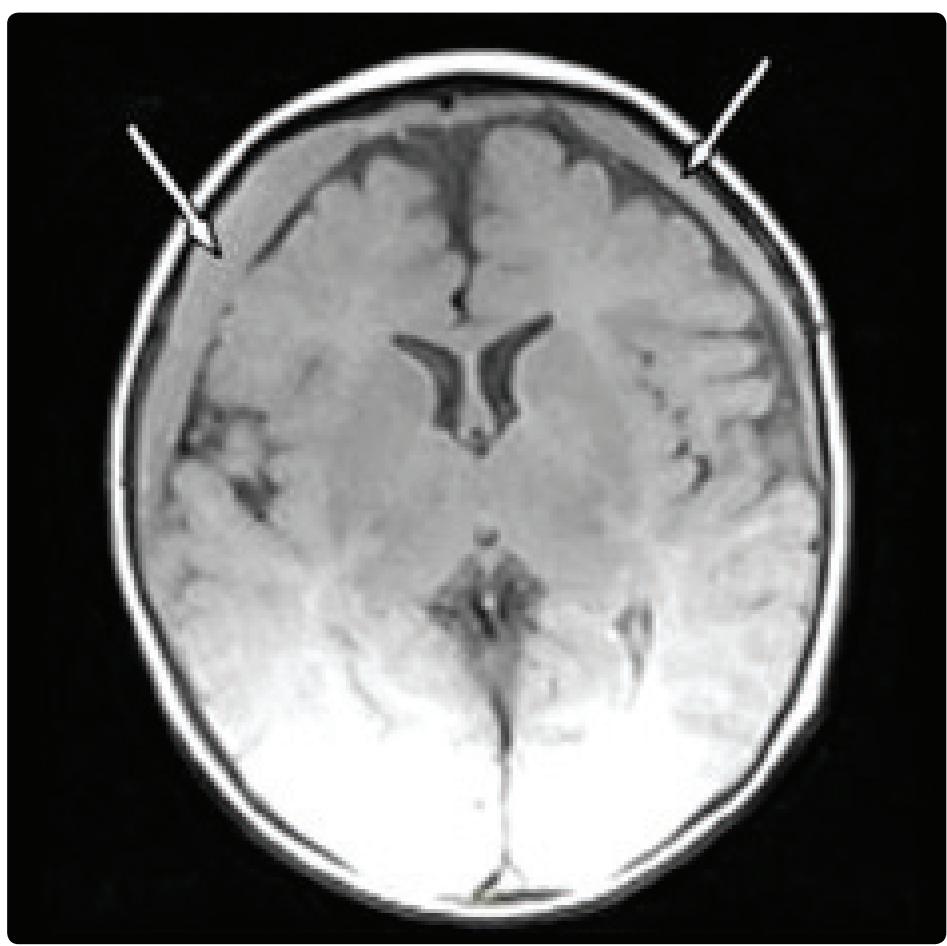

Fig. 3. Bilateral fronto-parietal subacute subdural hemorrhage in Ax T2 Flair weighted cranial MRI (Case 3). 
Table 1. Demographic and clinical features of patients related to child abuse

\begin{tabular}{|c|c|c|c|}
\hline Features & Patient 1 & Patient 2 & Patient 3 \\
\hline Age (month) & 3 & 12 & 3 \\
\hline Gender & Female & Male & Male \\
\hline History of overt head trauma & $\begin{array}{l}\text { Yes (admitted shaking } \\
\text { by mother } 6 \text { hours } \\
\text { prior to admission) }\end{array}$ & $\begin{array}{l}\text { Yes (recurrent shaking, } \\
\text { last shaking episode } \\
3 \text { weeks prior to admission) }\end{array}$ & $\begin{array}{l}\text { Yes (trivial fall } 6 \text { hours } \\
\text { prior to admission, } \\
\text { speculated unwitnessed } \\
\text { shaking by brother }\end{array}$ \\
\hline Seizures & Yes & No & Yes \\
\hline Intracranial bleeding & $\mathrm{ICH}, \mathrm{aSDH}$ & saSDH & saSDH \\
\hline External evidence of injury & No & No & No \\
\hline Skeletal survey & Normal & Normal & Normal \\
\hline Ocular findings & Unilateral RH & Unilateral RH & Bilateral RH \\
\hline Perpetrator & Mother (confessed) & Mother (confessed) & $\begin{array}{l}\text { Brother (questionable, } \\
\text { attributed by mother) }\end{array}$ \\
\hline
\end{tabular}

ICH: Intracerebral hemorrhage; aSDH: Acute subdural hemorrhage; saSDH: Subacute subdural hemorrhage; RH: Retinal hemorrhage.

pital admission, followed by vomiting and irritability that had lasted one day. Medical care was not sought at that time.

Case 3- A three-month-old male infant was admitted with irritability and seizures. The irritability had started suddenly, six hours before admission. The mother reported that she had dropped the baby onto the couch from her arms while she was standing. After this fall, he became hypotonic for one hour. He was referred to the university hospital by the local physician due to concern for intra-cranial injury. On arrival, he was lethargic and GCS was 13. Ophthalmologic examination revealed bilateral disseminated $\mathrm{RH}$ in the posterior poles and zones 1 and 2 of mid-peripheral areas extending to ora serrata (Figure $2 a, b)$. CBC including platelets, coagulation profile, and renal and liver function tests were within normal limits. The initial CT of cranium showed bilateral frontoparietal SDH. MRI scan was performed and showed bilateral frontoparietal subacute SDH (Figure 3). The mother was re-interviewed after the findings were discovered and spontaneously made the accusation that the infant's 10 year-old brother might have shaken him. However, she did not report any specific dates because she had not witnessed any shaking. Conservative treatment approach was opted for with anti-seizure medication. The infant was discharged on day 22 of admission. Demographic and clinical features of the patients are summarized in Table 1.

\section{DISCUSSION}

Shaken baby syndrome, a form of AHT, presents with a variety of symptoms which range from mild to severe and nonspecific to diagnostic. Since signs and symptoms at presentation may be non-specific and history of trauma is rarely reliable, health care providers must have a high index of suspicion when infants and young children present with subtle neurological signs such as lethargy, decreased level of consciousness, vomiting without fever and diarrhea, or unexplained, persistent irritability. If AHT is misdiagnosed, the victims may later be admitted with more severe morbidity or even mortality related to abuse. ${ }^{[9]}$ The cases mentioned in this paper were seen by primary physicians and referred with diagnoses other than AHT. All infants applied to the hospital with a history of neurological deterioration, intracranial bleeding, and retinal hemorrhages with no medical or plausible accidental explanation to account for the constellation of findings.

History-taking in suspect AHT cases is important. It is common that there will be no history of trauma to explain the findings. When there is a history of trauma, it may be a trivial trauma that does not fully explain the constellation of findings. ${ }^{[10]}$ It is also common to accuse older sibling for the acts of trauma as in the cases 1 and 3 in this series. ${ }^{[11]}$

Risk factors of AHT include single parenthood, mental health issues, domestic violence, substance abuse, and increased stress level within the family as well as child-related factors such as premature delivery, disability, poor parent-child bonding, etc. ${ }^{[1]}$ AHT can occur in all social strata. ${ }^{[11,12]}$ The families in these three cases are from low socioeconomic status. The perpetrators in two cases were the mothers with suspicion that it could be the case in the third one as well. In the literature, the perpetrator of AHT is a male caretaker in $70 \%$ of the cases, fathers being responsible for half the cases. ${ }^{[9,10]}$ This discrepancy can be explained by the fact that in Turkish families, males are rarely the solitary caretaker of young infants.

Bilateral RH are an important component of especially severe AHT. However, they are neither necessary nor sufficient for diagnosis. ${ }^{[13]} \mathrm{RH}$ are observed 
in 50 to $100 \%$ of AHT cases depending on the severity of cases included in case series..$^{[5,14]} \mathrm{RH}$ in AHT are typically bilateral; however, unilateral hemorrhages occur in nearly $15 \%$ of cases. ${ }^{[15]}$ The first two cases in this series involved mild/moderate injuries causing mild and unilateral RH, which is consistent with the literature. On the other hand, there were widespread bilateral intraretinal and preretinal hemorrhages, which were consistent with the more severe injury in case 3 .

The American Academy of Pediatrics recommends cranial CT scan without contrast as the preferred initial imaging study. ${ }^{[1]}$ If possible, MRI scan is advised 2-3 days later. MRI scan is helpful in demonstrating the parenchymal injury and in estimating the approximate age of the subdural hematoma. ${ }^{[16]}$ MRI scan should include diffusion restriction images as well to reveal subtle parenchymal brain damage. ${ }^{[17]}$ Initial head CT followed with an MRI scan were essential in establishing the diagnosis in all three cases presented in this report.

Differential diagnosis of AHT includes meningoencephalitis, aneurysm, arteriovenous malformation, coagulopathies, metabolic disorders like galactosemia and glutaric aciduria type 1, arachnoid cyst, osteogenesis imperfecta type 1 and 4, Terson's syndrome, accidental cerebral trauma, and increased intrathoracic pressure as in resuscitation, among others. ${ }^{[18]}$ The diagnosis of AHT in all three cases in this report was established by excluding other possible diagnoses via a comprehensive work-up.

All three cases in this study have been reported to Child Protective Services (CPS) and prosecutor's office. The children were not removed from their families. CPS assessed the psychosocial risks involving the index cases and siblings and developed a safety plan to include frequent home visits and family education. A forensic report was prepared and filed with District Prosecutor's Office. Trials are still ongoing.

In addition to challenges related to recognition of AHT, interdisciplinary management involving medical, child protective, and legal professionals is rarely available in Turkey. Although CPS protects children by providing social support, family visits, and investigation of siblings, limited resources for removed children such as institutions working at full capacity and limited foster care make it difficult for CPS to protect every child at risk.

In order to prevent AHT, every hospital providing delivery services should adopt a primary prevention program targeting parents of newborn infants in addition to advocating for public education programs. ${ }^{[19,20]}$ To protect abused infants, health care providers must be aware of the possibility of AHT in children especially under 2 years of age who are presented with neurologic symptoms, retinal hemorrhages, subdural hematoma, and brain damage that cannot be explained by a credible accidental history or other medical conditions. ${ }^{[1]}$ It is very important to provide more professional training on AHT to all agencies and staff who may potentially get involved in the management of these cases, including child protective workers, law enforcement, prosecutors, and judges. ${ }^{[21]}$

Conflict-of-interest issues regarding the authorship or article: None declared.

\section{REFERENCES}

1. American Academy of Pediatrics: Committee on Child Abuse and Neglect. Shaken baby syndrome: rotational cranial injuries-technical report. Pediatrics 2001;108:206-10.

2. Christian CW, Block R; Committee on Child Abuse and Neglect; American Academy of Pediatrics. Abusive head trauma in infants and children. Pediatrics 2009;123:1409-11.

3. King WJ, MacKay M, Sirnick A; Canadian Shaken Baby Study Group. Shaken baby syndrome in Canada: clinical characteristics and outcomes of hospital cases. CMAJ 2003;168:155-9.

4. Barlow KM, Minns RA. Annual incidence of shaken impact syndrome in young children. Lancet 2000;356:1571-2.

5. Keenan HT, Runyan DK, Marshall SW, Nocera MA, Merten DF, Sinal SH. A population-based study of inflicted traumatic brain injury in young children. JAMA 2003;290:621-6.

6. Duhaime AC, Gennarelli TA, Thibault LE, Bruce DA, Margulies SS, Wiser R. The shaken baby syndrome. A clinical, pathological, and biomechanical study. J Neurosurg 1987;66:409-15.

7. Balcı E, Gün I, Mutlu Şarlı Ş, Akpınar F, Yağmur F, Öztürk A, et al. Still an unknown topic: child abuse and "shaken baby syndrome”. Ulus Travma Acil Cerrahi Derg 2011;17:430-4.

8. Yağmur H, Asil F, Canpolat M, Per H, Coşkun A. Short distance falls and Shaken Baby Syndrome: case report. Turkiye Klinikleri J Med Sci 2010;30:766-71.

9. Oral R, Yagmur F, Nashelsky M, Turkmen M, Kirby P. Fatal abusive head trauma cases: consequence of medical staff missing milder forms of physical abuse. Pediatr Emerg Care 2008;24:816-21.

10. Starling SP, Patel S, Burke BL, Sirotnak AP, Stronks S, Rosquist P. Analysis of perpetrator admissions to inflicted traumatic brain injury in children. Arch Pediatr Adolesc Med 2004; 158:454-8.

11. Listman DA, Bechtel K. Accidental and abusive head injury in young children. Curr Opin Pediatr 2003;15:299-303.

12. Dubowitz H, Bennett S. Physical abuse and neglect of children. Lancet 2007;369:1891-9.

13. Aryan HE, Ghosheh FR, Jandial R, Levy ML. Retinal hemorrhage and pediatric brain injury: etiology and review of the literature. J Clin Neurosci 2005;12:624-31.

14. Pierre-Kahn V, Roche O, Dureau P, Uteza Y, Renier D, Pierre-Kahn A, et al. Ophthalmologic findings in suspected child abuse victims with subdural hematomas. Ophthalmology 2003;110:1718-23.

15. Drack AV, Petronio J, Capone A. Unilateral retinal hemorrhages in documented cases of child abuse. Am J Ophthalmol 1999; 128:340-4.

16. Chabrol B, Decarie JC, Fortin G. The role of cranial MRI 
in identifying patients suffering from child abuse and presenting with unexplained neurological findings. Child Abuse Negl 1999;23:217-28.

17. Biousse V, Suh DY, Newman NJ, Davis PC, Mapstone T, Lambert SR. Diffusion-weighted magnetic resonance imaging in Shaken Baby Syndrome. Am J Ophthalmol 2002;133:249-55.

18. Matschke J, Herrmann B, Sperhake J, Körber F, Bajanowski T, Glatzel M. Shaken baby syndrome: a common variant of non-accidental head injury in infants. Dtsch Arztebl Int 2009;106:211-7.
19. Dias MS, Smith K, DeGuehery K, Mazur P, Li V, Shaffer ML. Preventing abusive head trauma among infants and young children: a hospital-based, parent education program. Pediatrics 2005;115:e470-7.

20. Purple Programme in National Center on Shaken Baby Syndrome. Available at: http://dontshake.org/sbs.php?topNavID $=4 \&$ subNavID=37\&navID=672 Accessed November 2011.

21. Sahin F, Cepik-Kuruoğlu A, Demirel B, Akar T, DuyanCamurdan A, Iseri E, et al. Six-year experience of a hospital-based child protection team in Turkey. Turk J Pediatr 2009;51:336-43. 